Electrochemical Technology Program Electrochemical Technology Program Electrochemical Technology Program
Reformers for the Production of Hydrogen from Methanol and Alternative Fuels for Fuel Cell Powered Vehicles

by R. Kumar, S. Ahmed, M. Krumpelt, and K. M. Myles 
Argonne National Laboratory, with facilities in the states of Illimois and ldaho, is owned by the United States govermment. and operated by The University of Chicago under the provisions of a contract with the Department of Energy.

\section{DISCL AIMER}

This report was prepared as an account of work sponsored by an agency of the United States Government. Neither the United States Government nor any agency thereof, nor any of their employees, makes any warranty, express or implied. or assumes any legal liability or responsibility for the accuracy. completeness, or use fulness of any information. apparatus, product, or process disclosed, or represents that its use would not infringe privately owned rights. Reference herein to any specific commercial product. process, or service by trade name, trademark. manufacturer, or otherwise, does not necessarily constitute or imply its endorsement, recommendation, or favoring by the United States Government or any agency thereof. The views and opinions of authors expressed herein do not necessarily state or reflect those of the United States Government or any agency thereof.

Reproduced from the hest avitable copy.

Avatiahle 60 DOE and DOE contractors from the

office of Scientilic and Technisal Informattion

P.O. Box 62

Oak Ridge. TN 376.31

Prices ar atiable trom $(6,15,576-840)$

Aribable to the public from the

National Technical Intormation Service

( AS. Department of Commerce

5285 Porl Royal Road

Springfield. VA 22161 


\author{
ARGONNE NATIONAL LABORATORY \\ 9700 South Cass Avenue \\ Argonne, Illinois 60439
}

\title{
REFORMERS FOR THE PRODUCTION OF HYDROGEN \\ FROM METHANOL AND ALTERNATIVE FUELS \\ FOR FUEL CELL POWERED VEHICLES
}

by

R. Kumar, S. Ahmed, M. Krumpelt, and K. M. Myles

Electrochemical Technology Program

Chemical Technology Division

August 1992

Prepared for

DOE Office of Propulsion Systems

Electric and Hybrid Propulsion Division 


\section{TABLE OF CONTENTS}

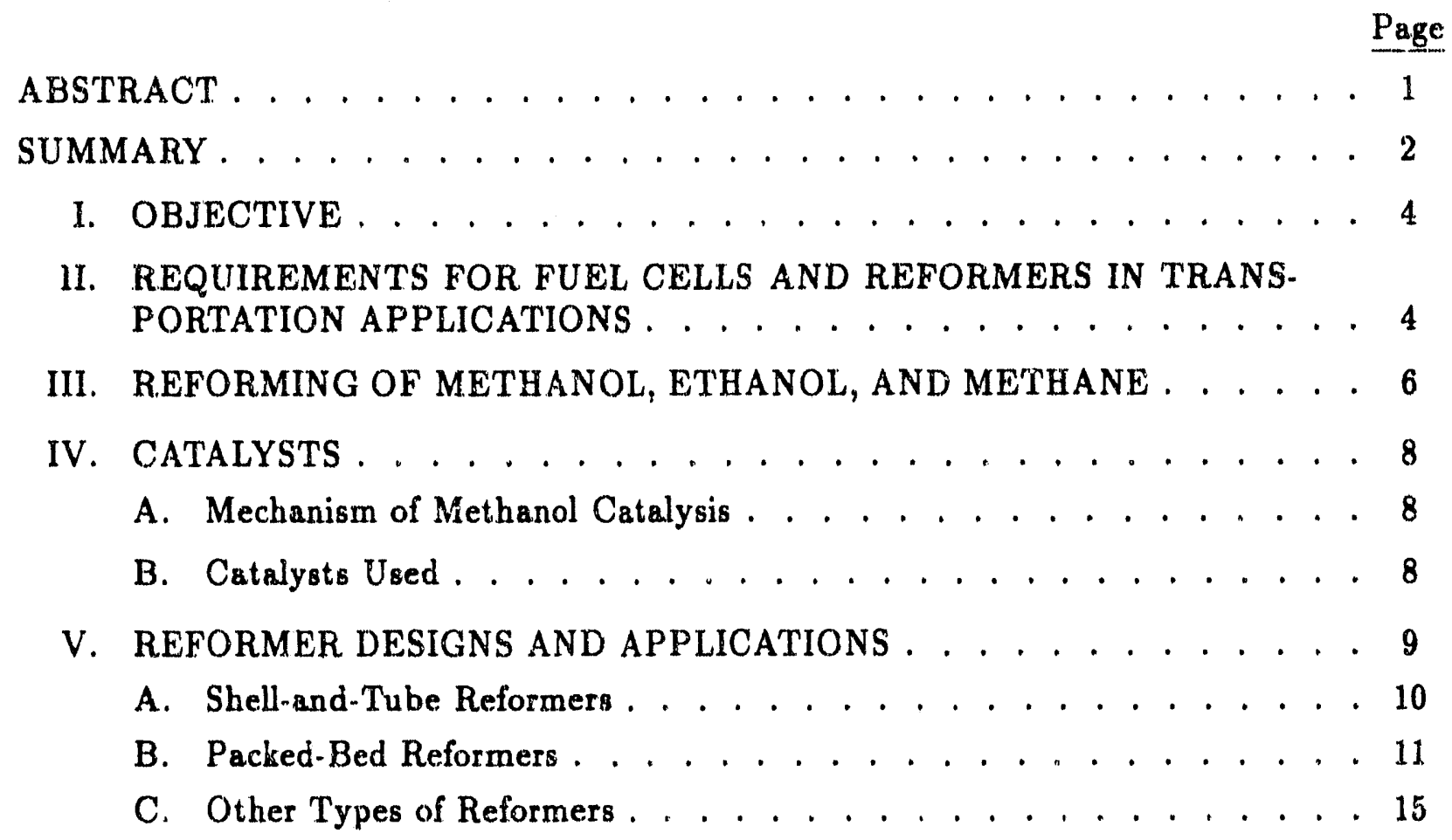

VI. PARTIAL CXIDATION VERSUS STEAM REFORMING . . . . . . . . . 16

A. Product Gas Composition . . . . . . . . . . . . . . . . . . . . . 16

B. Energy Efficiency . . . . . . . . . . . . . . . . . . . . 16

C. Start.Up and Variable Load Operation . . . . . . . . . . . . . . . 17

D. Miscellaneous Features . . . . . . . . . . . . . . . . . . . . . . 18

VII. DISCUSSION . . . . . . . . . . . . . . . . . . . . . 18

VIII. R\&D RECOMMENDATIONS . . . . . . . . . . . . . . . . 20

REFERENCES . . . . . . . . . . . . . . . . . 21 


\section{LIST OF FIGURES}

No.

1. Velocity and Power Profiles for the IETV-1 Simulated on the SAE J227aD Driving Schedule . . . . . . . . . . . . . . . 5

2. Velocity and Power Profiles for the IETV-1 Simulated on the SFUDS Driving Schedule . . . . . . . . . . . . . . . . . 5

3. Engelhard Corp. 50-kW Methanol Reformer . . . . . . . . . . . . . 10

4. Schernatic Diagrams of the Packed-Bed Methanol Reformers Developed for the Fuel Cell/Battery Powered Bus System . . . . . . . . . . . . . . . . . 12

5. Schematic Diagram of the Recirculating Methanol Reformer Developed at Los Alamos National Laboratory . . . . . . . . . . . . . . . . 12

6. Heat Exchange Reformer Developed by Haldor Topsoe . . . . . . . . . . 13

7. Schematic Diagrams of Packed-Bed Partial Oxidation Reformers . . . . . . . 14

\section{LIST OF TABLES}

No.

1. Reiormer Product Gas Compositions . . . . . . . . . . . . . . . . . 17 


\title{
REFORMERS FOR THE PRODUCTION OF HYDROGEN FROM METHANOL AND ALTERNATIVE FUELS FOR FUEL CELI POWERED VEHICLES
}

\author{
R. Kumar, S. Ahmed, M. Krumpelt, and K. M. Myles
}

\begin{abstract}
ABSTRAC'T
The objective of this study was (i) to assess the present state of technology of reformers that convert methanol (or other alternative fuels) to a hydrogen-rich gas mixture for use in a fuel cell, and (ii) to identify the R\&D needs for developing reformers for transportation applications.

Steam reforming and partial oxidation are the two basic types of fuel reforming processes. The former is endothermic while the latter is exothermic. Reformers are therefore typically designed as heat exchange systems, and the variety of designs used includes shell-and-tube, packed bed, annular, plate, and cyclic bed types. Catalysts used include noble metals and oxides of $\mathrm{Cu}$, $\mathrm{Zn}, \mathrm{Cr}, \mathrm{Al}, \mathrm{Ni}$, and $\mathrm{La}$.

For transportation applications a reformer must be compact, lightweight, and rugged. It must also be capable of rapid start-up and good dynamic performance responsive to fluctuating loads. A partial oxidation reformer is likely to be better than a steam reformer based on these considerations, although its fuel conversion efficiency is expected to be lower than that of a steam reformer. A steam reformer better lends itself to thermal integration with the fuel cell system; however, the thermal independence of the reformer from the fuel cell stack is likely to yield much better dynamic performance of the reformer and the fuel cell propulsion power system.

For both steam reforming and partial oxidation reforming, research is needed to develop compact, fast start-up, and dynarically responsive reformers. For transportation applications, steam reformers are likely to prove best for fuel cell/battery hybrid power systems, and partial oxidation reformers are likely to be the choice for stand-alone fuel cell power systems.
\end{abstract}




\section{SUMMARY}

The objective of this study was to assess the present state of technology of reformers for converting methanol and other alternative fuels to a hydrogen-rich gas mixture for use as the anode gas in a fuel cell. A related objective was to identify the R\&D needs for developing reformers that achieve the start-up, steady-state, and transient/dynamic performance requirements necessary for fuel ceil powered vehicles.

Methanol and other alternative fuels must be converted (reformed) to a hydrogen-rich gas for such fuels to be used in fuel cells. The reforming of methanol requires temperatures of $200^{\circ} \mathrm{C}$ or higher, while the reforming of ethanol or hydrocarbons requires temperatures $\geq 450^{\circ} \mathrm{C}$. For the proton exchange membrane fuel cell (operating temperature $\sim 80^{\circ} \mathrm{C}$ ) and the phosphoric acid fuel cell (operating temperature $\sim 190^{\circ} \mathrm{C}$ ), this tuel processing must be carried out in an external reformer, i.e., outside the fuel cell stack. For the higher temperature fuel cells, such as the molten carbonate (operating temperature $650^{\circ} \mathrm{C}$ ) and the solid oxide (operating temperature $1000^{\circ} \mathrm{C}$ ) fuel cells, this fuel conversion may be carried out within the fuel cell stack.

There is a variety of reformer designs, including shell-and-tube, packed bed, annular, plate, and cyclic bed reformers. Catalysts used include noble metals and the oxides of $\mathrm{Cu}, \mathrm{Zn}, \mathrm{Cr}, \mathrm{Al}, \mathrm{Ni}$, and $\mathrm{La}$, both as pellets and as monolithic blocks. Such reformers can produce hydrogen-rich gases from a variety of fuels, including methanol, ethanol, natural gas, propane, hexane, gasoline, diesel, and naphtha.

An external fuel reformer must process the methanol or other alternative fuel at the rate necessary for the fuel cell's maximum load. In addition, the reformer must be capable of fast response to the rapidly and widely fluctuating load on the fuel cell in a transportation application. Further, since the fuel processing occurs at an elevated temperature, the reformer must reach its operating temperature and produce hydrogen-rich fuel gas within a few seconds from cold start for general automotive applications; longer start-up times may be acceptable for fleet and mass transport applications.

Partial oxidation and steam reforming are the two basic types of reforming processes available for the conversion of methanol and other alternative fuels to a hydrogen-rich gas mixture. Partial oxidation reforming of methanol is exothermic overall (i.e., yields excess heat in the process) and produces a reformed gas containing $48 \% \mathrm{H}_{2}, 20 \% \mathrm{CO}_{2}, 11 \% \mathrm{H}_{2} \mathrm{O}$, and $21 \% \mathrm{~N}_{2}$. Steam reforming of methanol is endothermic overall (i.e., requires the input of external thermal energy) and yields a product gas containing $63 \% \mathrm{H}_{2}, 22 \% \mathrm{CO}_{2}, 11 \% \mathrm{H}_{2} \mathrm{O}$, and only $4 \% \mathrm{~N}_{2}$.

From thermodynamic analyses, we have estimated that a fuel cell system with a partial oxidation reformer has a gross energy efficiency of $29.4 \%$. In a fuel cell system with a steam reformer, the gross energy efficiency ranges from $31.7 \%$ to $44 \%$, depending on whether or not the waste heat from the fuel cell stack can be used to vaporize the methanol and water and/or to provide the heat of reaction. The lower efficiency of the partial oxidation reformer is offset, however, by its potentially much superior load following dynamic performance, as discussed below. 
Commercial processes have long been employed in the petroleum and petrochemical industries for the manufacture of hydrogen by steam reforming and partial oxidation of hydrocarbon feedstocks, such as natural gas, propane, butane, and naphtha. Similarly, technology has been developed for the steam reforming of methanol for steady load conditions in stationary applications and in hybrid power transportation applications. For example, methanol reformers have been developed by Energy Research Corp. and by Booz, Allen and Hamilton, Inc., for a program to develop a fuel cell/battery powered bus. These reformers give high conversion and good product quality when operated under design conditions. However, they have poor response to variable load requirements, and are not likely to be acceptable for transportation use in stand-alone fuel cell systems. Even for hybrid systems, it is desirable to reduce their size, weight, and start-up times.

Some reformers are being developed specifically for transportation applications. An example is the reformer with a high gas recirculation rate being developed by Los Alanos National Laboratory. That design substantially improves the reforming system's dynamic performance. Issues of fast enough start-up and adequately high heat transfer rates, however, have not yet been resolved fully.

In a generic sense, for use in transportation applications, a partial oxidation reformer is likely to have start-up and dynamic performance characteristics superior to those of a steam reformer because of the exothermic versus endothermic reaction, and because of the rapid and efficient direct heat transfer between the combustion products and the process gas. Also, a partial oxidation reformer is likely to be mechanically simpler and more compact than a steam reformer, making it more desirable for transportation applications.

The fuel reformer can be thermally integrated with the rest of the fuel cell system, or operated independently. In a thermally integrated system, the thermal energy requirements of the reformer are met, at least in part, by the excess heat generated in the fuel cell stack; in a thermally independent reformer, heat required by the reforming process is provided by the combustion of the fuel methanol itself. For fuel cell/battery propulsion systems, where the fuel cell operates at essentially constant power output, thermal integration is practical. For stand-alone fuel cells in automotive applications, where the fuel cell output must vary widely and rapidly, including periods of operation at idle or standby conditions, thermal integration of the reformer with the rest of the fuel cell system is likely to be impractical. For thermally independent systems, partial oxidation and steam reforming offer comparable energy efficiencies.

None of the methanol reformers presently available has demonstrated the performance capability needed for an automotive system powered by a stand-alone fuel cell. It is recommended that a reformer capable of processing $15-25 \mathrm{~kg} / \mathrm{h}(33-55 \mathrm{lb} / \mathrm{h})$ of methanol be developed for this specific application. Such a reformer should incorporate a small and lightweight multiple-catalyst bed, direct heat transfer (partial oxidation), and water injection. It should be designed to operate thermally independently from the rest of the fuel cell system. Even for fuel cell/battery systems, it is recommended that the presently available steam reformers be improved further to reduce their size, weight, and start-up times by incorporating design features that enhance heat transfer. 


\section{OBJECTIVE}

The objective of this study was to assess the present state of technology of retormers for converting methano? (and other alternative fuels) to a hydrogen-rich gas mixture to be used as the anode gas in a fuel cell and to determine their adaptability to use in a fuel cell powered vehicle. To this end, we examined the requirements for a stand-alone fuel cell and reformer in transportation applications, investigated the thermodynamics involved in the reforming of methanol (as well ethanol ard methane), reviewed the literature on catalysts for the production of hydrogen from methanol, reviewed the literature on current reformer designs and applications, and determined the advantages and disadvantages of the two basic kinds of reformer ; (partial oxidation and steam reforming). On the basis of this information, we provide recommendations for use of reformers with fuel cell powered vehicles and give some suggestions for future technology development needs.

\section{REQUIREMEN'TS FOR FUEL CELLS AND REFORMERS IN TRANSPORTATION APPLICATIONS}

Fuel cells are being developed for use in automotive propulsion systems as alternatives for the internal combustion engine in buses, vans, and passenger cars. ${ }^{1,2}$ Low emissions of pollutants, high fuel energy conversion efficiencies, superior acceleration, low noise and vibration, and the possibility of using coal- or biomass-derived alcohols rather than petroleum-based fuels are the major motivations.

Adaptation of fuel cells to vehicle use, however, poses some severe challenges. In addition to being cost-competitive with current and projected conventional technology, the fuel cell power subsystem must be able to provide acceptable dynamic response to power demand fluctuations, high enough power density to fit within the weight and space limitations of vehicle design, and quick start up. It must also satisfy other considerations, such as ruggedness, drivability, safety, and long operating lifetimes.

These challenges are being met, at least in a limited sense. A multiyear program is underway to demonstrate a small bus powered by a methanol-fueled fuel cell/battery for urban transportation. ${ }^{3}$ For this bus, the fuel cell subsystem provides the average power requirement of $50 \mathrm{~kW}$ on an essentially steady basis, while the battery subsystem provides the surge power needed for acceleration and hill climbing.

One issue that has a great bearing on the adaptability of fuel cells to transportation applications is the conversion of the primary fuel to hydrogen or a hydrogen-rich gas mixture suitable for use in a fuel cell. Hydrogen can be produced from methanol and other alternative fuels by reforming (with or without steam) or catalytic oxidation. The desired features for such a portable reformer include rapid start-up, dynamic performance responsive to fluctuating loads, efficient and complete fuel conversion, small size and weight, simplicity of construction and operation, long life, and low cost.

For a stand-alone fuel cell system for a vehicle, perhaps the most important operational requirement is the ability to supply the necessary power on demand for the dynamically fluctuating load. For example, the simulated velocity and power profiles for a small car, the IETV-1, operating on the SAE J227aD driving schedule are shown in Fig. 1. 
As the vehicle accelerates from 0 to $72.4 \mathrm{~km} / \mathrm{h}$ in $28 \mathrm{~s}$, the power demand increases rapidly to $21.7 \mathrm{~kW}$ at $14 \mathrm{~s}$, followed by a gradual reduction to $15.1 \mathrm{~kW}$ by $28 \mathrm{~s}$. During vehicle cruise at $72.4 \mathrm{~km} / \mathrm{h}$ the power demand is $6.9 \mathrm{~kW}$ for the next $50 \mathrm{~s}$, followed by a drop to $0 \mathrm{~kW}$ as the vehicle slows to a stop. The Federal Urban Driving Schedule (FUDS) and its simplified version, the SFUDS, are more demanding in terms of both the power fluctuations and the peak power required for the same vehicle. The velocity and power profiles for the IETV-1 simulated on the SFUDS are shown in Fig. 2. In addition to a more complex velocity and power profile than was the case for the $\mathrm{J} 227 \mathrm{aD}$, the peak power requirement rises sharply to $29.3 \mathrm{~kW}$. The nominal cruise power is $10-30 \%$ of peak power demand, while sustained power is $\sim 75 \%$ of peak power. On the SFUDS schedule the vehicle's power demand undergoes 15 step changes in $6 \mathrm{~min}$; in an actual urban driving situation, the fluctuations are typically more numerous, more complex, and, of course, more irregular.
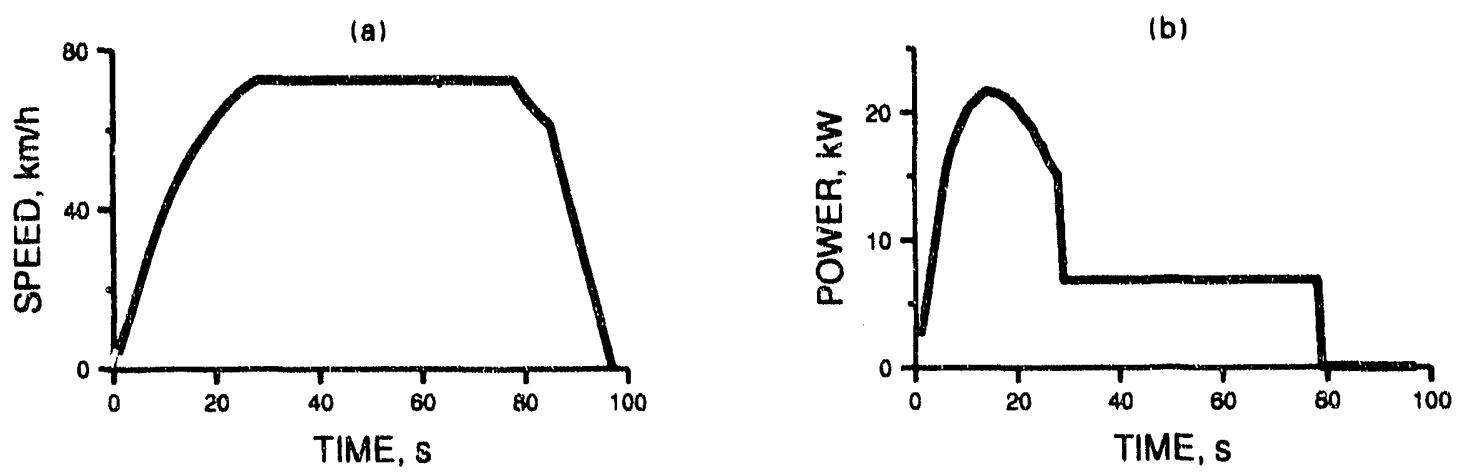

Fig. 1. Velocity and Power Profiles for the IETV-1 Simulated on the SAE J227aD Driving Schedule: (a) Velocity vs. Time and (b) Power vs. Time

(a)

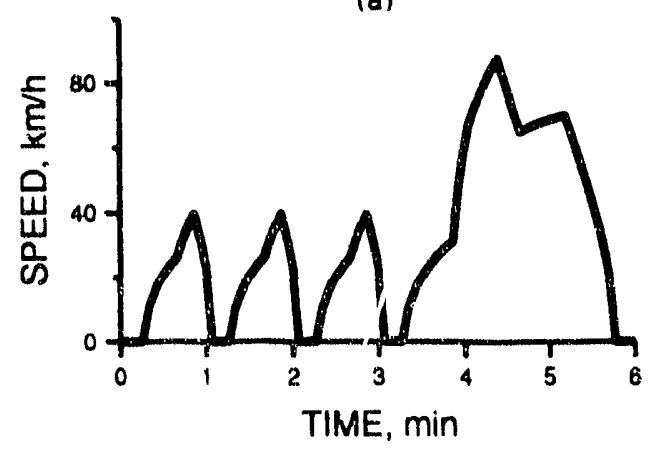

(b)

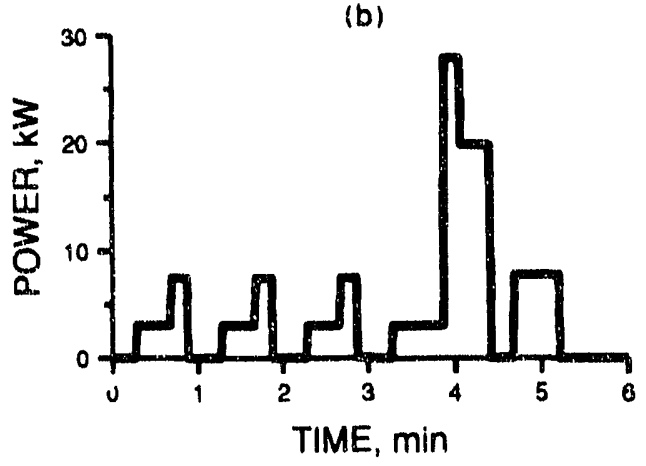

Fig. 2. Velocity and Power Profiles for the IETV-1 Simulated on the SFUDS Driving Schedule: (a) Velocity vs. Time and (b) Power vs. Time

To be suitable for transportation applications, therefore, the fuel cell power system must respond rapidly to wide fluctuations in power demand, as well as operate in the nominal idle, cruise, and sustained high-power conditions. The fuel reformer must, in turn, operate 
with highly variable fuel flow rates yet maintain high conversion yields and efficiencies at all points in the typical driving profiles.

In addition, the reformer must be capable of rapid start-up, so that the hydrogen-rich gas mixture is available at least as quickly as the fuel cell stack is ready to deliver power from a cold start. For fleet operations, it may be possible to maintain the reformer and the fuel cell stack in stand-by conditions to eliminate start-up times. For other applications, the reformer must be able to begin delivering useful concentrations and amounts of hydrogen within several seconds, assuming that the fuel cell stack can also begin delivering electric power in the same time frame. There is some tlexibility in this start-up time if the system includes a suitable battery and/or hydrogen storage to meet the initial starting needs.

\section{REFORMING OF METHANOL, ETHANOL, AND METHANE}

When considering different fuels for use in fuel cell powered vehicles, methanol has clear advantages in terms of fuel storage and distribution because it call be used with minimal disruption to the present liquid fuel (gasoline, diesel) distribution network. ${ }^{4}$ Methanol is a commodity chemical; it can be manufactured from coal, natural gas, or other feedstocks; and it can be easily reformed to hydrogen at low temperatures. Higher molecular weight hydrocarbon or alcohol contaminants in commercial grade methanol can, however, reduce the reforming efficiencies by raising the reforming temperature and by producing esters, ethers, alkenes, and higher alcohols in the product gas. ${ }^{5}$ Even with clean methanol, trace amounts of dimethyl ether, methane, and formaldehyde may be formed.

For a fuel cell system operating on vaporized methanol as the fuel, the overall reaction is

$$
\mathrm{CH}_{3} \mathrm{OH}(\mathrm{g})+\frac{3}{2} \mathrm{O}_{2}(\mathrm{~g}) \rightarrow \mathrm{CO}_{2}(\mathrm{~g})+2 \mathrm{H}_{2} \mathrm{O}(\mathrm{g})
$$

where the enthalpy $\left(\Delta \mathrm{H}_{298}^{\circ}\right)$ and free energy $\left(\Delta \mathrm{G}_{298}^{\circ}\right)$ are $-676.1 \mathrm{~kJ}$ and $-689.1 \mathrm{~kJ}$, respectively, for this reaction. Thus, if methanol could be used directly in a fuel cell, theoretically $689.1 \mathrm{~kJ}$ of energy could be obtained from a mole of methanol; however, direct electrochemical oxidation of methanol has not yet been demonstrated on any significant scale. Therefore, the methanol (or any of the other alternative fuels) must first be converted to hydrogen or a hydrogen-rich gas mixture before it can be effectively used in a fuel cell.

Hydrogen may be produced from methanol by either partial oxidation or steam reforming. In a partial oxidation or auto-thermal reformer, the methanol is first vaporized and then dissociated into carbon monoxide and hydrogen. The carbon monoxide is then preferentially oxidized by using a suitable catalyst:

$$
\begin{aligned}
\mathrm{CH}_{3} \mathrm{OH}(\mathrm{l}) & \rightarrow \mathrm{CH}_{3} \mathrm{OH}(\mathrm{g}) & \Delta \mathrm{H}_{298}^{\circ}=+37.49 \mathrm{~kJ} \\
\mathrm{CH}_{3} \mathrm{OH}(\mathrm{g}) & \rightarrow \mathrm{CO}(\mathrm{g})+2 \mathrm{H}_{2}(\mathrm{~g}) & \Delta \mathrm{H}_{298}^{\circ}=+90.64 \mathrm{~kJ} \\
\mathrm{CO}(\mathrm{g})+\frac{1}{2} \mathrm{O}_{2}(\mathrm{~g}) & \rightarrow \mathrm{CO}_{2}(\mathrm{~g}) & \Delta \mathrm{H}_{298}^{\circ}=-282.99 \mathrm{~kJ}
\end{aligned}
$$

Thus, overall,

$$
\mathrm{CH}_{3} \mathrm{OH}(\mathrm{l})+\frac{1}{2} \mathrm{O}_{2}(\mathrm{~g}) \rightarrow 2 \mathrm{H}_{2}(\mathrm{~g})+\mathrm{CO}_{2}(\mathrm{~g}) \quad \Delta \mathrm{H}_{298}^{\circ}=-154.86 \mathrm{~kJ}
$$


In a steam reformer, the methanol and water are vaporized, the methanol is dissociated, and the carbon monoxide is oxidized by steam:

$$
\begin{aligned}
\mathrm{CH}_{3} \mathrm{OH}(\mathrm{l}) & \rightarrow \mathrm{CH}_{3} \mathrm{OH}(\mathrm{g}) & \Delta \mathrm{H}_{298}^{\circ}=+37.49 \mathrm{~kJ} \\
\mathrm{H}_{2} \mathrm{O}(\mathrm{l}) & \rightarrow \mathrm{H}_{2} \mathrm{O}(\mathrm{g}) & \Delta \mathrm{H}_{298}^{\circ}=+44.02 \mathrm{~kJ} \\
\mathrm{CH}_{3} \mathrm{OH}(\mathrm{g}) & \rightarrow \mathrm{CO}(\mathrm{g})+2 \mathrm{H}_{2}(\mathrm{~g}) & \Delta \mathrm{H}_{298}^{\circ}=+90.64 \mathrm{~kJ} \\
\mathrm{CO}(\mathrm{g})+\mathrm{H}_{2} \mathrm{O}(\mathrm{g}) & \rightarrow \mathrm{H}_{2}+\mathrm{CO}_{2}(\mathrm{~g}) & \Delta \mathrm{H}_{298}^{\circ}=-41.16 \mathrm{~kJ}
\end{aligned}
$$

Thus, overall,

$$
\mathrm{CH}_{3} \mathrm{OH}(\mathrm{l})+\mathrm{H}_{2} \mathrm{O}(\mathrm{l}) \rightarrow 3 \mathrm{H}_{2}(\mathrm{~g})+\mathrm{CO}_{2}(\mathrm{~g}) \quad \Delta \mathrm{H}_{288}^{\circ}=+130.99 \mathrm{~kJ}
$$

For reforming pre-vaporized methanol and water, the overall reaction is

$$
\mathrm{CH}_{3} \mathrm{OH}(\mathrm{g})+\mathrm{H}_{2} \mathrm{O}(\mathrm{g}) \rightarrow 3 \mathrm{H}_{2}(\mathrm{~g})+\mathrm{CO}_{2}(\mathrm{~g}) \quad \Delta \mathrm{H}_{298}^{\circ}=+49.48 \mathrm{~kJ}
$$

Thus, the net reaction in partial oxidation reforming (Eq. 5) is exothermic, i.e., excess heai is generated, even after the endothermic vaporization and dissociation steps (Eqs. 2 and 3) are taken into account. Since the absorption of thermal energy and the emission of thermal energy both occur in the same process gas stream, and since the overall reaction is exothermic, direct heat transfer between the heating and the heated fluids can be used. In direct heat transfer there is no physical boundary or interface between the hot and the cold media. An example of direct heat transfer is the heating of water by injecting steam into it. In such a heat exchanger the heat flux can be very high, leading to a compact heat exchanger. Moreover, the temperature difference between the two fluids leaving the heat exchanger can approach zero (and usually does), resulting in a very efficient mode of heat transfer. Thus, in partial oxidation, the entire heat of combustion can be used to vaporize and reform the reactants in a compact unit with minimum loss of energy from the system.

On the other hand, the overall reaction in steam reforming (Eqs. 10 or 11) is endothermic and requires the input of external thermal energy. The energy requirements are less if the methanol and/or the water are vaporized when fed to the reformer; nevertheless, heat must be supplied to the process gas in a steam reformer. Since in this case the heating medium must necessarily differ from the process gas, indirect heat transfer must be used. In indirect heat transfer, the heating fluid is kept separate from the heated fluid by a physical barrier impervious to either fluid. As a result, the heat flux in indirect heat exchange is relatively small, leading to the requirement of a relatively large heat exchange surface area (and consequently heat exchanger size). Also, the temperature difference between the two fluids must not approach zero, resulting in relatively inefficient heat transfer between the two fluids. Indeed, because of the overriding heat transfer considerations, steam reformers are typically designed as heat exchangers and often incorporate special design features to enhance the heat transfer in them.

Both in partial oxidation and in steam reforming the product gas contains residual carbon monoxide. For use in a phosphoric acid fuel cell, this $\mathrm{CO}$ must be reduced to less than $1 \%$; for use in a proton exchange membrane fuel cell, the residual $\mathrm{CO}$ must be reduced to trace amounts. The concentration of residual $\mathrm{CO}$ in the product gas is reduced by injection 
of $\mathrm{H}_{2} \mathrm{O}$ along with the $\mathrm{CH}_{3} \mathrm{OH}$ in partial oxidation, and by the use of excess $\mathrm{H}_{2} \mathrm{O}$ in steam reforming. Even so, the $\mathrm{CO}$ concentration may have to be reduced to acceptable levels in a follow-on processing step of selective oxidation by using au appropriate catedyst."

For methanol, the dissociation occurs at temperatures $\geq 400^{\circ} \mathrm{C}$. The selective oxidation of $\mathrm{CO}$ to $\mathrm{CO}_{2}$ occurs at all temperatures from room temperature to $400^{\circ} \mathrm{C}$ or higher in the presence of a suitable catalyst. The oxidation of $\mathrm{CO}$ by $\mathrm{H}_{2} \mathrm{O}$ occurs at $\sim 200^{\circ} \mathrm{C}$ over a suitable catalyst.

For etharol, the dissociation occurs at $5 \% \mathrm{~d}-700^{\circ} \mathrm{C}$, with subsequent oxidation of the $\mathrm{CO}$ to $\mathrm{CO}_{3}$ occurring at $-200^{\circ} \mathrm{O}$ for stean reforming and at essentially all temperatures from room temperature and $x p$ for partial oxidation reforming.

For methane, the diswociation reaction occurs at $\geq 800^{\circ} \mathrm{C}$; ihe subsequent carbon oxidation occurs at lower temperatures.

Stearn reforming and partial oxidation reforming have been demonstrated for methanol, ethanol, natural gas, gasoline, diesel, naphtha, and other hydrocaibona.

\section{TV. CATALYSTS}

Based on models containing selected species, Amphlett et al. ${ }^{6}$ have shown that the most favorable thermodynamic conditions for the production of hydrogen from methanol are a temperature of $225^{\circ} \mathrm{C}$, low pressure, and the presence of excess water. At these conditions, however, the formation of carbon (soot) and methane are also favored thermodynamically, and these undesirable producta must be inhibited by using an appropriate selective catalyoi. Kinetic atudies ${ }^{7}$ have shown that the dissociation of nethanol (Eqs. 3 and 8 ) is the ratedetermining step.

\section{A. Mechanism of Methanol Catalysis}

There are two schools of thrught regading the mechanism by which methanol is reformed to hydrogen. Amphlett et al. believe that Eqs, 8 and 9 represent the true mechanism. On the other hand, Sprinqer et $a .^{8}$ and Vanderborgh al, ${ }^{10}$ contend that the reaction occurs through an alternate oxidation and reduction of active sites on the catalyst, where the methanol first reduces a site by taking away the lattice oxygen and producing $\mathrm{CO}_{2}$ and $\mathrm{H}_{2}$. The reduced site is then oxidized by water to produce $\mathrm{H}_{2}$. This is supported by the observation that methanol cracking, which uses the same catalyst, occurs at temperatures near $400^{\circ} \mathrm{C}$, while stean reforming of methanol can occur at temperatures as low as $200^{\circ} \mathrm{C}$. Further, the catalyst activity appears to be fifected by the hydrogen-to-steam ratio, perhaps controlled by the rapid reaction of hydrogen with the lattice axygen atoms.

\section{B. Catalysts Used}

There is wide consensus that the oxides of copper and zinc give satisfactory methanol conversion, although some researchers have included alumina, ${ }^{11}$ iron, and chromium ${ }^{12}$ in their catalyst formulations. Lee et al. ${ }^{13}$ found that the addition of alkaline earth metal to the copper and ainc oxides provides greater selectivity toward $\mathrm{CO}_{2}$ (over $\mathrm{CO}$ ) but with a slight decrease in catalyst activity. The highest selectivity for $\mathrm{CO}_{2}$ was observed with $\mathrm{Ba}-\mathrm{Cu}-\mathrm{Za}$ at $250^{\circ} \mathrm{C}$. 
Engelhard Corp. ${ }^{14}$ tested a copper/zinc oxide catalyst (T2107RS) and a zinc/ chromium oxide catalyst (C70-2RS), both manufactured by Union Carbide for methanol reformirg. The T2107RS catalyst contain $27.5 \% \mathrm{Cu}, 1.0 \% \mathrm{Cr}, 11.6 \% \mathrm{Zn}$, and $29.8 \% \mathrm{Al}_{2} \mathrm{O}_{3}$; the $\mathrm{C}^{\prime \prime} 0.2 \mathrm{RS}$ catalyat cortains $22 \% \mathrm{Cr}$ and $55 \% \mathrm{Zn}$ (for each catalyst, the balance is oxygen; compositions are given in weight percent). The T2107RS showed far greater activity than the C70-2RS for methanol reforming at $250-300^{\circ} \mathrm{C}$. On the other hand, the C70-2RS was

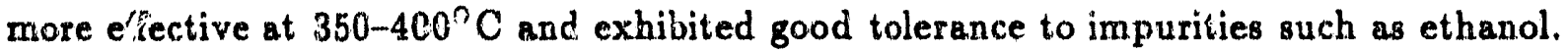

Mitsubishi Electric Corp. ${ }^{15}$ has patented a monolithic Y-type zeolite supported catalyst. This zeolite was impregnated with sydroxides of $\mathrm{Cu}, \mathrm{Zn}, \mathrm{Al}$ and $\mathrm{La}$, and then oxidized by firing for $3 \mathrm{~h}$ at $300^{\circ} \mathrm{C}$. The resulting catalyst contained the metals $\mathrm{Cu}, \mathrm{kn}, \mathrm{Al}$, and $L_{a}$ in the ratio $10: 7: 1: 1$ and yielded a mett $3 . n$ ol conrersion of $94 \%$ without significant pressure drop.

For the partial oxidation reforming of methanol, Jenkins and Shutt ${ }^{16}$ used a copper/silica catalyst along with a mixture of copper/silica and palladium/silica near the outlet from the reactor. Essentially complete conversion of the methanol was obtained, although in the absence of water in the fue feed, roughly equivalent amounts of $\mathrm{CO}$ and $\mathrm{CO}_{2}$ were produced; with the addition of water to the fuel input stream, most of the CO was converted to $\mathrm{CO}_{2}$ by the water gas shift reaction. For ethanol, Jenkins and Shutt used a $\mathrm{Pt} / \mathrm{La}_{2} \mathrm{O}_{3}$ catalyst coated with $\gamma-\mathrm{Al}_{2} \mathrm{O}_{3}$, but no details on catalyst performance wers provided.

A metal-supported monolithic nickel catalyst for reforming methane has been discussed by Rohatgi and Voecks. ${ }^{17}$ With this catalyst operated at $\sim 800^{\circ} \mathrm{C}$, the catalyst activity and pressure drop performance were found to be superior to conventional paikedbed catalysts.

\section{REFORMER DESIGNS AND APPLICATIONS}

Fuel reformers are commonly used in industrial practice for the manufacture of hydrogen needed in the petroleum refining and chemical process industries. The common feedstocks are natural gas, propane, butane, and naphtha, and two most commonly used processes are steam reforming and partial oxidation in the presence of steam. ${ }^{18}$

Fuel reformers for the production of hydrogen for use in fuel cells have been developed more recently. Much of this development work, however, has concentrated on stationary applications, with essentially constant system load and procers throughput. Reformers have been built and tested for converting methanol and natural gas to a hydrogen-rich fuel gas. Feforming of a variety of other fuels (including ethanol, gasoline, diesel, and napintha) has also been demonstrated. For constant-load, stationary applications, steam reforming is preferred over partial oxidation reforming because the "rrmer provides a higher overall system efficiency. As discussed above, steam reforming is endothermic and requires the input of thermal energy. As a result, heat transfer to the reaction zone of the reformer is a principal design consideration, and the reformer size and its dynamic performance are primarily determined by heat transfer rather than catalytic activity. 
Thus, most of the reformers developed to date have been designed around heat exchange equipment configurations. These include the convertional shell-and-tube, plate, packed-bed, and double-pipe heat exchangers, as well as modified versions of these types.

\section{A. Shell-and-Tube Reformers}

A conventional shell-and-tube type reformer is typified by the $50-\mathrm{kW}$ methanol reformer developed by Engelhard Corp. for On-site Integrated Energy Systems. ${ }^{14}$ The reformer subsystem is shown schematicaly in Fig. 3a, while details of the baffle arrangement within the shell are shown in Fig. $3 \mathrm{~b}$. Th: 17 -in. $(43-\mathrm{cm})$ dia reformer shell contains 120 tubes [4-ft (1.2-m) long, 1-in. $(2.5-\mathrm{cm})$ dia] packed with $1 / 8$-in. $(0.3-\mathrm{cm})$ pellets of the T2107RS catalyst (see Sec. IV.B). The reformer provides cocurrent flow of the combustion gases in the shell and the process gas in the tubes.

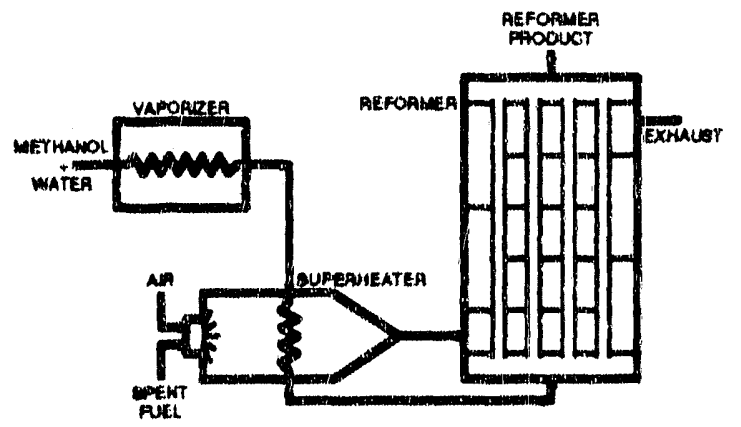

(a)

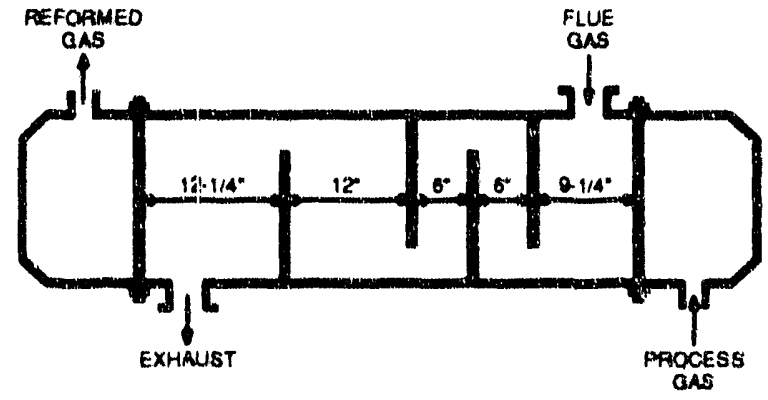

(b)

Fig. 9. Engelhard Corp. 50-kW Methanol Reformer: ${ }^{14}$ (a) Schematic Diagram of the Reformer Subsystem and (b) Baffle Arrangement within the Reformer Shell

From preliminary studies, Engelhard found that increasing the tube diameter increased the temperature gradients within the tubes and decreased the fuel conversion. Mathematical modeling of the reactor showed that the process gas temperature dropped sharply writhin the first $10 \%$ of the tube length, where most of the conversion took place. The tube-side heat transfer coefficient increased with increasing concentration of $\mathrm{H}_{2}$ in the process gas; however, the limiting heat transfer coefficient was found to be the one on the shell side. The shell-side heat transfer coefficient increased as the number of baffles was increased, but this also sharply increased the shell-side pressure drop. The optimized design, shown in Fig. 3b, used close spacing of baffles in the fast reaction zone at the inlet end, with increased spacing between the baffles downstream.

At the design feed rate of the process gas containing steam/methanol in the ratio 1.3:1, with inlet temperatures of $452^{\circ} \mathrm{C}$ for the feed gas and $481^{\circ} \mathrm{C}$ for the combustion gas, the reformer provided $99.8 \%$ conversion and yielded a product containing $74.6 \% \mathrm{H}_{2}$, $23.9 \% \mathrm{CO}_{2}$, and $1.4 \% \mathrm{CO}$ on a dry basis. Increasing the feed rate by $33 \%$ decreased the tnethanol conversion to $92.3 \%$, illustrating the importance of sustaining the design operating conditions for this type of reformer. 
A similar reformer using a dual-catalyst system has been patented by Fuji Electric Co., Ltd. ${ }^{10} \mathrm{~A}$ high temperature catalyst (e.g., $\mathrm{Cu}-\mathrm{Cr}-\mathrm{Zn}$ ) at the reactor inlet provides fast kinetics, while a low temperature catalyst (e.g., $\mathrm{Cu}-\mathrm{Zn}$ ) at the outlet end provides high conversion. A fast-start reformer, incorporating additional burners within the shell as independent heat sources, has also been patented by Fuji. ${ }^{20}$

Kawasakj Heavy Industries, Ltd., has also developed a shell-and-tube reformer for methanol. ${ }^{21}$ In this reformer the tubes are packed with the reforming cataly'st, and the shell side is packed with metal or ceramic particles for improved shell-side heat transfer, resulting in a compact design. The process gas is split between the shell and the tubes. The bulk of the gas flows through the tubes and is converted to the reformate; the portion of the raw gas fed to the shell side is mixed with air and burned. This combustion on the shell side provides the heat of reaction for the reforming reactions. A reformer of a similar design has been patented by Toshiba Corp. for the convere on of natural gas and other hydrocarbons to hydrogen. ${ }^{22}$

A version of shell-and-tube heat exchange reformer incorporating extended surfaces (fins) in the tubes and Rasch $\mathrm{g}$ rings on the shell side was developed by Union Carbide for the steam reforming of natural gas. ${ }^{23}$ In a later development the fuel dissociation and reforming steps were physically separated but were still carried out in one internally insulated vessel; ${ }^{24}$ a catalyst-free reaction zone was included between the primary and secondary reforming beds.

\section{B. Packed-Bed Reformers}

A variety of packed-bed configurations have been developed for natural gas and methanol reformers. Even in these, howz/er, the primary consideration is heat transfer between the heating medium and the process gas. Versions of packed-bed reformers have also been tested for the partial oxidation reforming process.

A packed-bed reformer using an annular catalyst bed with concentrically located vaporizer and burner has been developed by Energy Research Corp. ${ }^{25}$ and is shown in Fig. 4a. A somewhat similar reformer developed by Booz, Allen \& Hamilton, Inc. ${ }^{2 C}$ is shown schematically in Fig. 4b. Each of these designs uses a concentric down-flow burner. The methanol/water fuel mixture is vaporized, superheated, and then passed through the catalyst bed. Although in principle the two reformers are similar, they use different combustion gas and process fluid flow schemes to achieve the requisite thermal energy input into the process gas.

A packed-bed methanol reformer with a high gas recirculation rate is being developed at Los Alamos National Laboratory. ${ }^{1}$ The structural design is shown schematically in Fig. 5 . An internal fan recirculates the reformate through the catalyst bed at a rate of 20 to 50 times the net fuel processing rate to maintain the bed at the desired reaction temperature and to provide high convective heat transfer rates. In this fuel processing scheme, the reforming step is followed by a shift converter (to reduce the $\mathrm{CO}$ concentration to less than $0.6 \%$ ) and a preferential oxidation unit (to reduce the $\mathrm{CO}$ to less than $10 \mathrm{ppm}$ ). ${ }^{27}$

Haldor Topsoe, Inc., has developed a heat exchange reformer for natural gas that uses two separate cataly'st beds housed in a single vessel. ${ }^{28}$ The heat exchange processes within 


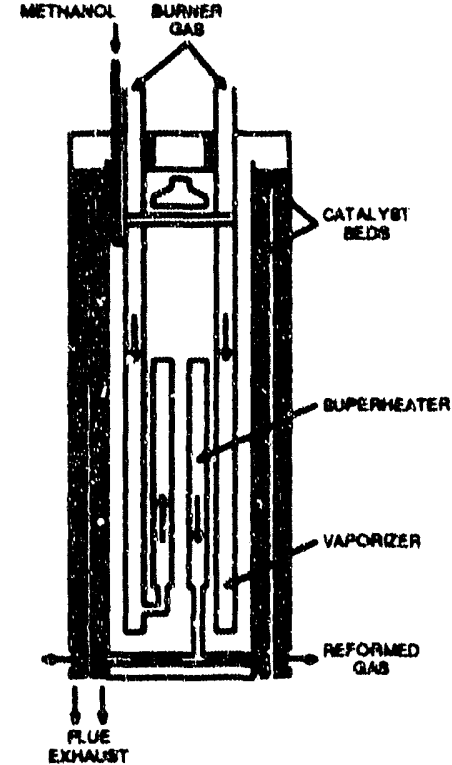

(a)

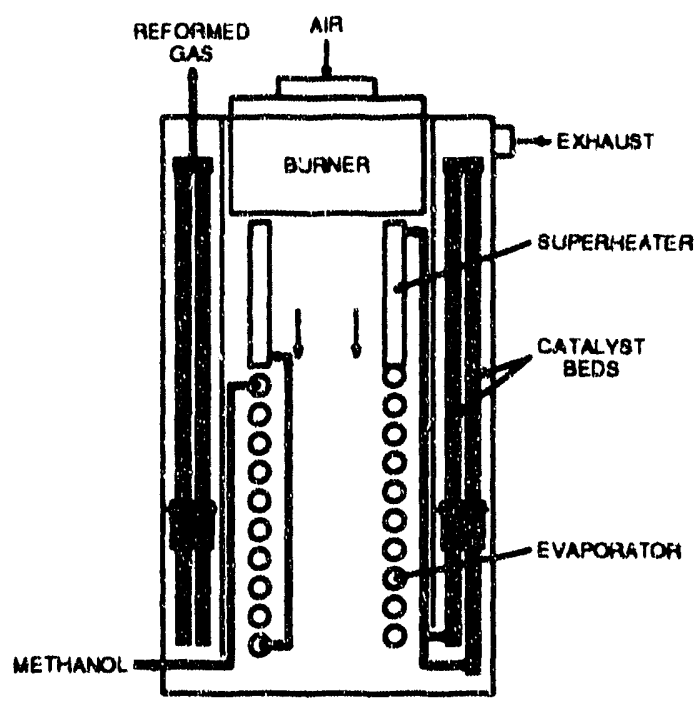

(b)

Fig. 4. Schematic Diagrams of the Packed-Bed Methanol Reformers Devsloped for the Fuel Cell/Battery Powered Bus System: (a) Energy Research Corporation Design ${ }^{25}$ and (b) Booz, Allen \& Hamilion Design ${ }^{26}$

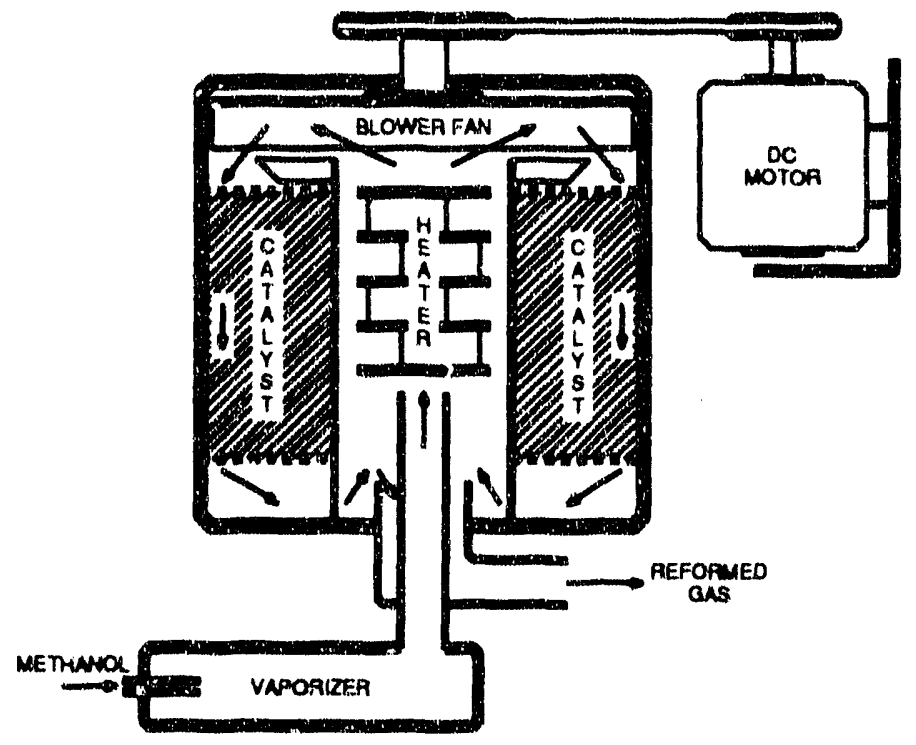

Fig. 5. Schematic Diagram of the Recirculating Methanol Reformer Developed at Los Alamos National Laboratory ${ }^{1}$ 


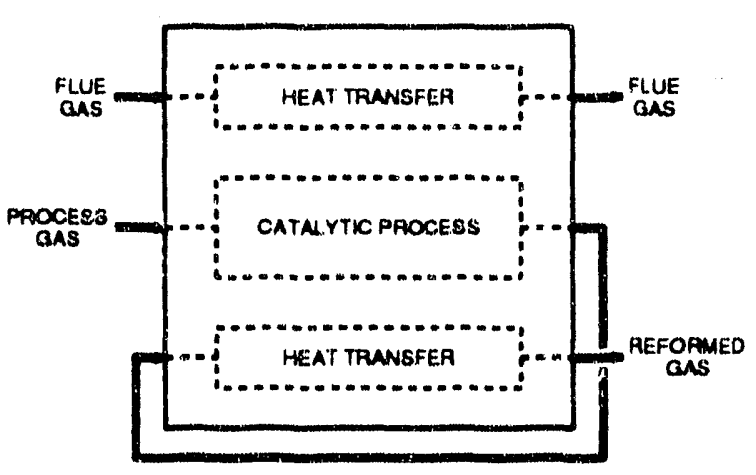

(a)

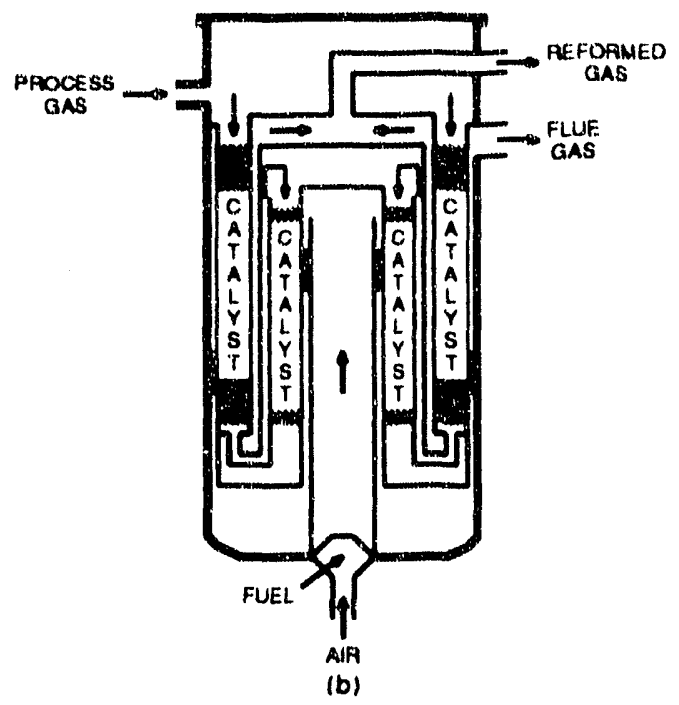

Fig. 6. Heat Exchange Reformer Developed by Haldor Topsoe..$^{28}$ (a) Schematic Diagram of the Heat Exchange Processes and (b) Structural Design of the Reformer

this reformer are shown schematically in Fig. 6a, while Fig. 6b shows the structural design of the reformer. The burner for the heat of reaction is placed within the reformer. The two catalyst beds are in series. The first bed is heated by countercurrent flow of hot flue gases and the effluent from the second bed, while the second bed is heated by cocurrent flow of flue gases. Test data during proof of concept and demonstration runs were presented at Fuel Cell Seminars. ${ }^{29,30}$

A packed-bed reformer incorporating fuel recycle and hydrogen purification has also been developed by Haldor Topsoe. ${ }^{31}$ The processing steps described consist of catalytic reforming at $1.5-2.5 \mathrm{~atm}$ and $250^{\circ} \mathrm{C}$ followed by condensation and recycle of unconverted methanol and water. Hydrogen is separated from the reactor effluent by pressure swing adsorption on molecular sieves.

A compact-design packed-bed methanol reformer incorporating an isothermal reaction zone followed by an adiabatic reaction zone has been patented by Asahi Engineering Co., Ltd. ${ }^{32}$ The lower isothermal zone is packed with alumina catalyst balls, while the upper adiabatic zone is packed with $\mathrm{Cu}-\mathrm{Cr}$ catalyst pellets.

Another dual-section pecked-bed reformer has been developed by Hitachi, Ltd. ${ }^{33}$ A fraction of the feed gas is burned in the upper bed, which is packed with a combustion catalyst. The heat generated is used for the steam-reforming reaction in the lower bed, which is packed with a reforming catalyst.

A packed-bed reforming process that uses co-injection of $\mathrm{CO}_{2}$ with the process feed gas has been developed at the Institut Francais du Petrole. ${ }^{12}$ In this process methanol, water, and carbon dioxide are passed over a fixed bed of $\mathrm{CuO}-\mathrm{Fe}_{2} \mathrm{O}_{3}-\mathrm{Cr}_{2} \mathrm{O}_{3}$ catalyst at $150-400^{\circ} \mathrm{C}$. Co-injection of carbon dioxide is claimed to increase methanol conversion. 
A combination evaporator/reformer has been developed by Mitsubishi Electric Corp. ${ }^{34}$ In this device the packed catalyst bed is placed parallel to the methanol evaporator. Heat is supplied to both by a common burner. Heat distribution to each is varied by moving the burner nozzle and by adjusting a combustion baffle to redirect the gas flow within the vessel. With this arrangement cold-start times are significantly reduced.

A three-catalyst packed-bed reformer that employs partial oxidation has been tested by Jet Propulsion Laboratory (JPL) for the production of hydrogen for use in fuel cells, ${ }^{35}$ and a dual-catalyst packed-bed reformer that also employs partial oxidation has been developed at the Johnson Mathey Technology Center. ${ }^{16}$ The two reformers are shown schematically in Fig. 7.
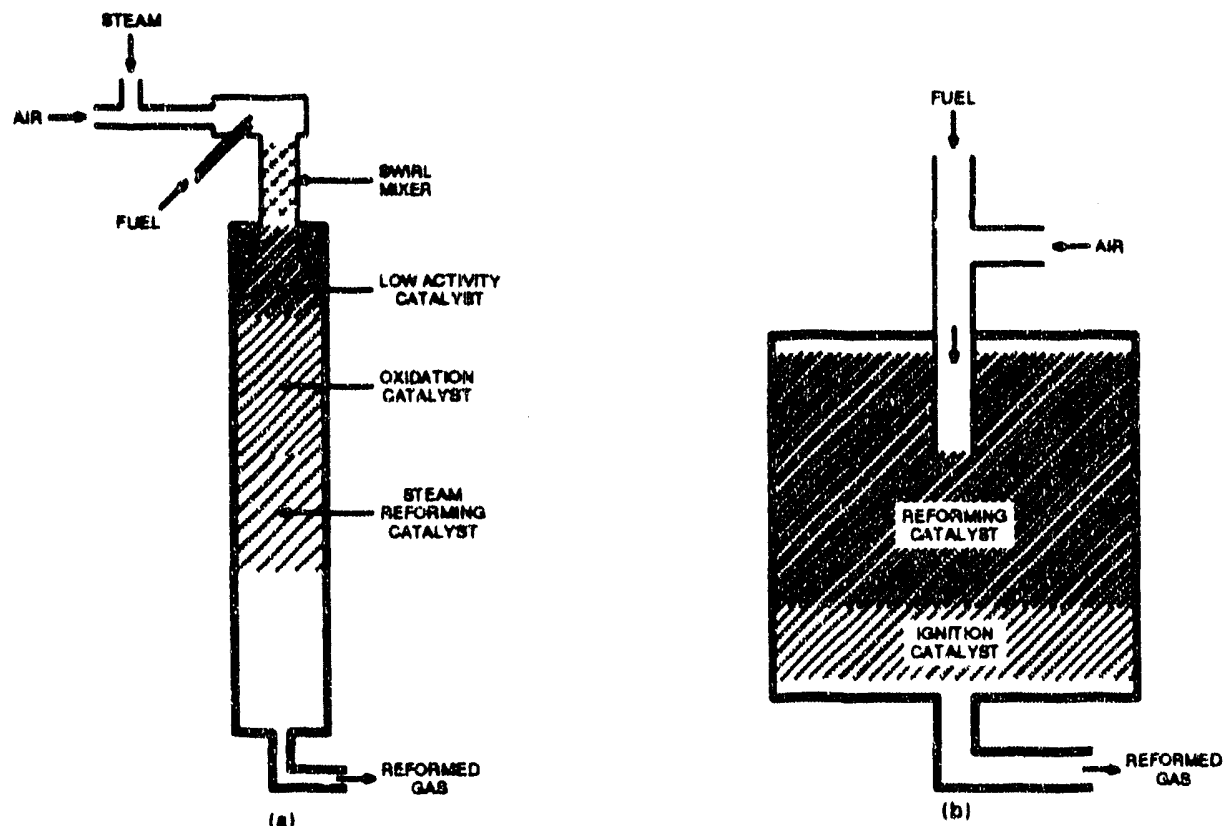

Fig. 7. Schematic Diagrams of Packed-Bed Partial Oxidation Reformers: (a) The JPL Autothermal Reformer ${ }^{35}$ and (b) The Johnoon Mathey Hot Spot ${ }^{\mathrm{TM}}$ Reformer ${ }^{16}$

In the JPL reformer the fuel is injected into a premixed stream of air and steam just ahead of a swirl mixer at the inlet to the reformer. A conical refractory-lined entrance zone in the reactor eliminates any dead spots. A combination of three different catalysts is used: at the entrance, a $\mathrm{NiO}-\mathrm{ZrO}_{2}$ catalyst with low activity effects a gradual increase in the reactant temperature and suppresses carbon formation; in the middle zone, a $\mathrm{NiO}-\mathrm{Al}_{2} \mathrm{O}_{3}$ $\mathrm{CaO}$ type of oxidation catalyst with high void fraction oxidizes the fuel; and in the last zone, a $\mathrm{NiO}-\mathrm{Al}_{2} \mathrm{O}_{3}-\mathrm{MgO}$ steam-reforming catalyst with high activity maximizes hydrogen production.

The Johnson Mathey Hot Spot ${ }^{T M}$ reactor contains a $\mathrm{Cu}$-Si catalyst in the main reaction zone, and a mixture of $\mathrm{Cu}-\mathrm{Si}$ and $\mathrm{Pd}-\mathrm{Si}$ in the lasi $20 \%$ of the bed. The palladium makes the reactor capable of self-ignition. The feed gas mixture consisting of methanol, 
water, and air is injected into the middle of the main reaction zone. At start-up the methanol is oxidized at the reformer exit. The reaction zone then moves upstream toward the point of injection. The feed inlet velocity stabilizes the reaction front well inside the packed bed, where the heat of methanol oxidation effectively provides the heat of reforming for the bulk process gas by direct heat transfer. In addition to reforming methanol, this reactor has been tested successfully with methane (natural gas), propane (LPG), n-hexane, petroleum ether, lead-free gasoline, and commercial grade diesel fuel (the last using a $1 \% \mathrm{Pt}-3 \% \mathrm{Cr}$-Si catalyst formulation).

\section{Other Types of Reformers}

In addition to the above reformer designs, plate-and-frame, multistage, and other types of reformers have been discussed in the literature

A plate-and-frame type of reformer similar in concept to a filter press has been developed by Ishikawajima-Harima Heavy Industries (IHI). ${ }^{36}$ The reformer is designed around a series of heat transfer plates that have a reforming catalyst on one side and a combustion catalyst on the other side. In addition to efficient heat transfer, the design provides for low thermal stresses in the structure due to matched temperature gradients in the reforming and combustion sides.

During the early development of the solid polymer electrolyte (SPE) fuel cell, General Electric Co. designed a methanol reformer that uses an annular two-pass catalyst bed enclosed in an air preheater chamber. ${ }^{37}$ Vaporized methanol is catalytically cracked into hydrogen and carbon monoxide using the heat generated by fuel combustion as the combustion gases pass through the core of the reactor. The cracked gases are mixed with steam (from the fuel cell exhaust) and fed to the shift reactor, which reduces the CO to less than $0.2 \%$ in the product gas.

Imperial Chemical Industries has developed a two-step reforming process, ${ }^{38,39}$ where the preheated feedstock (natural gas, naphtha, or methanol) and steam mixture is first adiabatically reformed, yielding the partially reformed gas. This gas is then passed through the annular catalyst in a double-tube reformer. The heat for the secondary reforming is supplied by passing a hot gas stream through the central tube.

International Fuel Cells has demonstrated a two-column cyclic reformer for producing hydrogen from diesel fuel. ${ }^{40}$ Each column alternates between hydrogen production and bed regeneration modes. Packed with catalyst and other material of high thermal mass, the column is first heated by burning spent anode gas within the column. On attaining the desired temperature, the column is switched to reforming duty. The catalyst bed acts as a very effective heat exchanger, storing heat during regeneration and supplying it during the reforming cycles (2-4 min each) with minimum bed temperature swings, eliminating the need for heat exchange with external sources. This reformer concept offers fast transient capability and recovers automatically from off-design operating conditions. In addition, any carbon deposited in the catalyst bed during the reforming cycle is burned off during the regeneration (combustion) cycle. 
A multistage reformer has been developed by JGC Corp., ${ }^{41}$ where the steam-tomethanol ratio is kept below 1.0 and the reaction temperature in each reactor is kept 10 $50^{\circ} \mathrm{C}$ above the dew point. The product from the first stage is mixed with additional steam before going into the second stage. Thus, the overall excess steam is greatly reduced in this process without adversely affecting product quality.

Finally, a methanol reformer incorporating several advanced features has been developed by Chemical Energy Specialists. ${ }^{43}$ Its design is said to provide exceptional conduction heat transfer within both the catalyst bed and an integral feed vaporizer, improved convection heat transfer in the catalyst bed with internal recirculation obtained without moving parts, a unique internal burner with rapid and high turn-down capability, and a simplified overall control methodology.

\section{PARTIAL OXIDATION VERSUSS STEAM REFORMING}

Each of the two basically different kinds of fuel reforming has certain advantages as well as disadvantages from the perspective of potential application to automotive systems.

\section{A. Product Gas Cornposition}

Nominally, the product of partial oxidation reforming should consist of $41 \% \mathrm{H}_{2}$, $21 \% \mathrm{CO}_{2}$, and $38 \% \mathrm{~N}_{2}$, if all the $\mathrm{CO}$ is oxidized to $\mathrm{CO}_{2}$. In practice, however, $\mathrm{CO}$ and $\mathrm{CO}_{2}$ appear in roughly equal proportions in the product gas, which thus contains $\sim 13 \%$ each of $\mathrm{CO}$ and $\mathrm{CO}_{2}, 50 \% \mathrm{H}_{2}$, and $24 \% \mathrm{~N}_{2}$. With the addition of $\mathrm{H}_{2} \mathrm{O}$, such reforming occurs as a combination of partial oxidation and steam reforming. With a 1:1 molar mixture of $\mathrm{CH}_{3} \mathrm{OH}$ and $\mathrm{H}_{2} \mathrm{O}$ as the reactant, this mode of partial oxidation reforming can yield a gas mixture containing approximately $51 \% \mathrm{H}_{2}, 19 \% \mathrm{CO}_{2}, 10 \% \mathrm{H}_{2} \mathrm{O}, 1 \% \mathrm{CO}$, and $19 \% \mathrm{~N}_{2}$ as the product.

With steam reforming, the nominal product composition is $75 \% \mathrm{H}_{2}$ and $25 \% \mathrm{CO}_{2}$ if a stoichiometric amount of water is used. In practice, an excess of water is necessary to reduce the amount of $\mathrm{CO}$ in the product gas. With $50 \%$ excess $\mathrm{H}_{2} \mathrm{O}$, the product gas composition is $67 \% \mathrm{H}_{2}, 21 \% \mathrm{CO}_{2}, 11 \% \mathrm{H}_{2} \mathrm{O}$, and $1 \% \mathrm{CO}$.

For the low temperature proton exchange membrane (PEM) fuel cell, a final CO removal step is required to avoid poisoning of the noble metal catalyst in the anode. This may be done using selective oxidation at $\geq 400^{\circ} \mathrm{C}$ with a small amount of air over a suitable catalyst, such as platinum. For a steam-injected partial oxidation reformer, the removal of $1 \% \mathrm{CO}$, using twice the amount of air necessary to oxidize the $\mathrm{CO}$, would produce a final reformed gas containing $48 \% \mathrm{H}_{2}, 20 \% \mathrm{CO}_{2}, 11 \% \mathrm{H}_{2} \mathrm{O}$, and $21 \% \mathrm{~N}_{2}$; selective oxidation of $1 \% \mathrm{CO}$ from a steam reformer product would produce a gas containing $63 \% \mathrm{H}_{2}, 22 \% \mathrm{CO}_{2}$, $11 \% \mathrm{H}_{2} \mathrm{O}$, and $4 \% \mathrm{~N}_{2}$. These product gas compositions are summarized in Table 1. For both the low temperature PEM and the higher temperature phosphoric acid fuel cells, the difference in hydrogen concentration of $48 \%$ versus $63 \%$ leads to a Nernst voltage penalty of $6 \mathrm{mV}(\sim 0.5 \%)$ for the partial oxidation reformer versus the steam reformer.

\section{B. Energy Efficiency}

Partial oxidation reforming of $\mathrm{CH}_{3} \mathrm{OH}$ produces excess thermal energy, which can be 
Table 1. Reformer Product Gas Compositions

\begin{tabular}{llccc}
\hline & & \multicolumn{3}{c}{ Gas Composition, \% } \\
\cline { 4 - 5 } $\begin{array}{l}\text { Reforming } \\
\text { Process }\end{array}$ & Gas & Nominal & $\begin{array}{c}\text { With } \\
\text { Excess } \\
\text { Water }\end{array}$ & $\begin{array}{c}\text { After CO } \\
\text { Removal }\end{array}$ \\
\hline Partial Oxidation & $\mathrm{H}_{2}$ & 41 & 51 & 48 \\
& $\mathrm{CO}_{2}$ & 21 & 19 & 20 \\
& $\mathrm{H}_{2} \mathrm{O}$ & - & 10 & 11 \\
& $\mathrm{CO}$ & - & 1 & - \\
& $\mathrm{N}_{2}$ & 38 & 19 & 21 \\
\hline Stearn Reforming & $\mathrm{H}_{2}$ & 75 & 67 & 63 \\
& $\mathrm{CO}_{2}$ & 25 & 21 & 22 \\
& $\mathrm{H}_{2} \mathrm{O}$ & - & 11 & 11 \\
& $\mathrm{CO}$ & - & 1 & - \\
& $\mathrm{N}_{2}$ & - & - & 4 \\
\hline
\end{tabular}

used to vaporize the methanol and to heat the reformed product gas by direct heat transfer, a very rapid and efficient means of heat transfer. The net energy effect is that, from the $726.5 \mathrm{~kJ}$ of the higher heating value (HHV) for one mole of the input $\mathrm{CH}_{3} \mathrm{OH}$, the partial oxidation reformer yields $\mathrm{H}_{2}$ with a theoretical maximum electrochemically available energy of $474.4 \mathrm{~kJ}$. If the fuel cell system is operated with an electrochemical fuel utilization of $75 \%$ and a cell voltage of $0.7 \mathrm{~V}$, its gross efficiency would be $29.4 \%$, based on the HHV of the input fuel methanol.

Steam reforming of $\mathrm{CH}_{3} \mathrm{OH}$ requires the input of external energy by indirect heat transfer, a relatively slow and inefficient means of heat transfer. If the vaporizing and reforming energy is provided from the rest of the fuel cell system itself (i.e., from the fuel cell stack waste heat and the energy in the spent fuel leaving the stack), the net effect is to convert the $726.5 \mathrm{~kJ}$ of the $\mathrm{HHV}$ for an input mole of $\mathrm{CH}_{3} \mathrm{OH}$ to a theoretical maximum electrochemically available energy of $711.6 \mathrm{~kJ}$ as $\mathrm{H}_{2}$. With an electrochemical fuel utilization of $75 \%$ and a cell voltage of $0.7 \mathrm{~V}$, the gross efficiency for the fuel cell system would then be $44 \%$. On the other hand, if the vaporizing and reforming energy is provided by the combustion of additional methanol, then the gross efficiency for the fuel cell drops to $31.7 \%$, which is only a little higher than the efficiency of the system with a partial oxidation reformer.

\section{Start-Up and Variable Load Operation}

The start-up and performance under varying loads can be much superior for the partial oxidation reformer compared to that of the steam reformer. This is because direct heat transfer in the partial oxidation reformer is much more efficient than the indirect heat transfer in a steam reformer. The partial oxidation reformer can be much more compact than a steam refurmer of equal methanol processing capacity due to the absence of heat transfer surfaces. Also, since the combustion products form part of the reformed gas itself, no separate reformer combustion exhaust stream is needed for the partial oxidation reformer. 
In addition, with the use of suitable oxidation catalysts, the partial oxidation reformer can be self-starting without the use of an ignition source.

\section{Miscellaneous Features}

The steam-reformer product gas leaves the reformer at $\sim 180-200^{\circ} \mathrm{C}$, which is comparable to the stack temperature in the phosphoric acid fuel cell. This reformate would need to be cooled to $\sim 80^{\circ} \mathrm{C}$ for use in a $\mathrm{PEM}$ system. The product gas from a partial oxidation reformer would be at a much higher temperature, perhaps $400^{\circ} \mathrm{C}$, and would require an appropriate heat exchanger to cool it down to the fuel cell stack temperature.

The hydrogen concentration in the partial oxidation product is lower than that in the steam reformer product. As a consequence, for the same power output from the fuel cell system, a 20-25\% greater flow rate of the anode gas would be needed in the fuel cell stack. This does not necessarily mean a higher input rate of methanol to the fuel cell system, however. The methanol fuel input rate is a function of the overall system efficiency and, for a given system power output, is only slightly greater for the partial oxidation system than for the steam reforming system if the latter is operated without using the stack waste heat for fuel and water vaporization.

Both the partial oxidation and the steam reformer require the addition of water to the process gas for good product quality; however, a partial oxidation reformer requires onethird less water for the same amount of methanol than is used in a steam reformer. The product of either reformer may require additional $\mathrm{CO}$ removal if it is to be used in a low temperature fuel cell.

The partial oxidation reformer is a mechanically simple system due to the absence of burners, baffles, heat transfer surfaces, and combustion manifolding and ducting; in it, process kinetics are not limited by heat transfer considerations. A steam reformer is relatively complex; it contains one or more burners (for spent fuel and fresh fuel), extended heat transfer surfaces, and combustion air and exhaust ductwork. In a steam reformer the limiting kinetic factor is the rate of heat transfer from the burner and the combustion product gases to the process gas stream. The partial oxidation reformer may, however, be subject to coking (deposition of carbon on the catalyst, rendering it inactive), particularly with higher hydrocarbons.

\section{DISCUSSION}

As discussed in Sec. II, a small passenger car driven on the SFUDS profile requires a power system capable $c$ f delivering up to $\sim 30 \mathrm{~kW}$ for at least several seconds. For the fuel cell/battery small urban bus, the fuel cell subsystem is required to provide $\sim 50 \mathrm{~kW}$ of power at essentially steady state. For system efficiencies of $\sim 30-45 \%$, the corresponding methanol consumption rate is $\sim 10-16 \mathrm{~kg} / \mathrm{h}(22-35 \mathrm{lb} / \mathrm{h})$ for the $30 \mathrm{~kW}$ system and $\sim 18-27 \mathrm{~kg} / \mathrm{h}$ $(40-60 \mathrm{lb} / \mathrm{h})$ for the $50 \mathrm{~kW}$ system.

Both partial oxidation and steam reforming of methanol (and other alternative fuels) have been discussed at some length in the literature. Most of the recent literature on the subject is in the form of patents in the U. S. and abroad. Steam reformers for methanol 
and natural gas for use with fuel cell systems have received considerable attention; partial oxidation reformers, while commercially used in industrial hydrogen manufacture, have not seen much development for fuel cell applications, presumably due to the lower efficiency of fuel cell systems employing such reformers. Enough information does exist in the literature, however, to reasonably assess the mexits of each type of reformer for use in fuel cell powered automotive applications.

Most of the fuel refoimers discussed in the literature were developed for use in power systems operated at essentially constant load, primarily for stationary applications, where efficiency is of primary importance. As a result, much of the effort has been devoted to development of steam reformers which, when thermally integrated with a fuel cell system, can yield gross system efficiency of $44 \%$ (for the fuel cell operating conditions discussed above). For automotive applications, however, rapid start-up, ability to handle varying loads, small size, and low weight are equally as important as the system efficiency, or perhaps even more so. To meet these performance requirements, the reformer may have to be thermally independent of the rest of the fuel cell system, in which case the gross system efficiency decreases to $\sim 30 \%$.

Since thermal integration of the reformer with the rest of the fuel cell system has such a marked effect on the system efficiency, the factors involved in devising an integrated system must be considered carefully. There are two major considerations in integrating a fuel reformer with the balance of the fuel cell power system for use in automotive applications. One is thermal integration, and the other is coupling of the dynamic performance of the reformer with that of the fuel cell stack. The two considerations are interrelated and can only be discussed in conjunction with each other.

For an automotive application, dynamic performance of the total system under widely and rapidly fluctuating loads is of primary importance, and thermal integration may be sacrificed, if necessary. On the other hand, for a fuel cell power system operating at essentially constant load, thermal integration of the reformer with the fuel cell stack and the rest of the power system is the only significant concern; dynamic performance of either the reformer or the fuel cell stack is unimportant.

In a fuel cell power system incorporating a steam reformer, energy is required to vaporize the methanol and water and to reform the vaporized fuel. Excess thermal energy is available in the system in the form of stack waste heat and as spent fuel. In principle, therefore, the energy requirements of vaporizing and reforming the fuel can be provided from this excess energy. In a dynamically varying system, however, the availability of this excess energy lags behind the demand for it.

For instance, consider a step increase in the power output required from the fuel cell stack. Vaporizing and reforming of the additional fuel require tnergy before the excess stack waste heat and the excess spent fuel become available. This happens after the stack begins delivering power at the higher demand level. This phase difference in the requirement and availability of thermal energy in the fuel cell power system suggests that the thermal subsystems of the stack and the vaporizer/reformer should be independent of each other. The vaporizer and reformer can be combined into one thermal subcomponent (indeed, a partial oxidation reformer performs both functions in one piece of hardware). In addition 
to being more responsive, the independent systems should be easier to operate and control. This independence does mean, however, that the power system would have to operate at a lower overall fuel use efficiency, as compared to a thermally integrated system. The excess energy is not necessarily wasted. It can be used to provide passenger compartment heating and cooling.

Even in a thermally independent system, a steam reformer is slightly more efficient than a partial oxidation reformer. The latter, however, is inherently more responsive to dynamic load fluctuations due to direct heat transfer for fuel vaporization and conversion, although design approaches such as process gas recirculation as used in the Los Alamos reformer ${ }^{1}$ can improve the dynamic performance of the steam reformer.

Considerable research $F$. $\mathrm{st}$ has been devoted to developing the steam reformer for automotive use, in particular in maximizing the fuel-to-hydrogen conversion selectivity and efficiency. Prototypical steam reformers have been developed by $\mathrm{ERC}^{25}$ and $\mathrm{BAH}^{26}$ for the fuel cell/battery bus propulsion system. Although these reformers have been successfully tested for a constant load application, their start-up times and dynamic performance are unacceptable for stand-alone fuel cell systems that provide automotive power. The Los Alamos recirculating reformer design ${ }^{1}$ attempts to provide rapid start-up and good dynamic performance, but relevant test data have not yet been published. Due to the indirect heat transfer, however, even this design is not likely to be as dynamically responsive as a partial oxidation reformer. Chemical Energy Specialists ${ }^{42}$ claims that its steam reformer provides

rapid start-up and quick response to load changes; however, no design details or operating data have been published.

In comparison, much less effort has been devoted to the development of partial oxidation reformers. A fuel processing system somewhat similar to the partial oxidation reformer was used in an earlier program sponsored by DOE through the National Renewable Energy Laboratory (formerly, the Solar Energy Research Institute). ${ }^{43}$ Under the alcohol fuels program in the early 1980 s a Ford Escort and its internal combustion engine were modified to run on methanol converted to a $\mathrm{H}_{2} / \mathrm{CO}$ mixture by partial oxidation. Although in that approach the $\mathrm{CO}$ content of the reformed gas was of no particular concern, the tests did demonstrate that a partial oxidation reformer can provide adequate dynamic performance. More recently, the Johnson Mathey Hot Spot ${ }^{\mathrm{TM}}$ reformer $^{16}$ was described in the literature. The test results did not indicate an acceptably short start-up time; no dynamic performance data were reported.

\section{R\&D RECOMMENDATIONS}

Among all the methanol reformers described and discussed in the literature, none has been demonstrated to possess the requisite performance capability for rapid start-up and dynamic response necessary for use in a stand-alone fuel cell system for automotive applications. The published information does strongly suggest, however, that by appropriately combining selected features of the various designs, it should be possible to develop a reformer that has the required start-up and operational characteristics. The desirable features of such a reformer include: 
- a platinum-group metal catalyst for self-ignition of the reformer;

- multiple catalysts for optimum operation of the oxidation, dissociation, and shift reactions;

- a small catalyst bed for a quick starting, light, and compact reformer;

- direct heat transfer (partial oxidation), perhaps combined with process gas recirculation, for rapid response to fluctuating loads;

- water injection for improved product quality; and

- a fuel processing scheme thermally independent of the rest of the fuel cell system.

In addition, further efforts are needed in the area of product quality, i.e., $\mathrm{CO}$ minimization, particularly for use of the reformer with the low temperature PEM fuel cell system.

For fuel cell/battery automotive applications, where the fuel cell is expected to of,erate at an essentially constant power output, a steam reformer can provide high efficiency by thermally integrating the reformer with the balance of the fuel cell system. The prototype reformers developed by $\mathrm{ERC}^{25}$ and $\mathrm{BAH},{ }^{26}$ although adequate for the present fuel cell bus program, ${ }^{3}$ can be improved further to reduce their size, weight, and start-up times by design modifications that enhance heat transfer. Such modifications might include the process gas recycling successfully used in the Los Alamos reformer ${ }^{1}$ or the design approaches claimed to be effective in the reformer developed by Chemical Energy Specialists. ${ }^{42}$ Such improvements in heat transfer are likely to result in substantial improvements in start.up and dynamic performance of the reformer and the entire fuel cell system.

It is recommended that DOE sponsor the development of a steam-injected, partialoxidation methanol reformer incorporating the features identified above, capable of processing $15-25 \mathrm{~kg} / \mathrm{h}(33-55 \mathrm{lb} / \mathrm{h})$ of methanol along with the appropriate amount of coinjected water. Such a reformer would be prototypical of the type and size of reformer needed for a stand-alone fuel cell system for automotive power. The objective of this effort should be to build a compact, lightweight, quick starting, and dynamically responsive reformer. The product gas from the reformer must be essentially free of carbon monoxide or must contain amounts of $\mathrm{CO}$ small enough to be reduced to a few parts per million by processes such as catalytic selective oxidation.

It is also recommended that DOE should continue efforts to improve the currently available steam reformers for use in hybrid power systems, with the objective to reducing their size, weight, and start-up times.

\section{REFERENCES}

1. Ross A. Lemons, "Fuel Cells for Transportation," J. Power Sources 29, 251-264 (1990).

2. R. Kumar, M. Krumpelt, and B. Misra, "Fuel Cells for Vehicle Propulsion Applications: A Thermodynamic Systems Analysis," Proc. of the 24th Intersoc. Ener. Conv. Eng. Conf., Washington, DC, August 6-11, 1989, pp. 1601-1606. 
3. Samuel Romano and L. Dean Price, "Installing a Fuel Cell in a Transit Bus," SAE Technical Paper Series No. 900178, Electric Vehicle Technology, International Congress and Exposition, Detroit, MI, February 26-March 2, 1990.

4. S. Srinivasan, "Potential Fuel Ceil System for Traxisportation Applications," Proceedings of the Fuel Cell in Transportation Applications Workshop, 1977, Los Alamos Scientific Laboratory Report LA-7270-C, p. 41 (1978).

5. G. E. Voecks, "On-board Production of Hydrogen for Vehicular Systems," Proceedings of Renewable Fuels and Advanced Power Sources for Transportation Workshop, National Rerewable Energy Laboratory Report SERI-CP-234-1707, p. 139 (1982).

6. J. C. Amphlett, M. J. Evans, R. A. Jones, R. F. Mann, and R. D. Weir, "Hydrogen Production by Catalytic Steam Reforming of Methanol. Part 1: The Thermodynamics," Can. J. Chem. Eng., 59, 720-727 (1981).

7. J. C. Amphlett, M. J. Evan.s, R. F. Mann, and R. D. Weir, "Hydrogen Production by Catalytic Steam Reforminz of Methanol. Part 2: Kinetics of Methanol Decomposition using Girdler (G66B Catalyst," Can. J. Chem. Eng. 63, 605-611 (1985).

8. J. C. Amphlett, R. F. Mann, and R. D. Weir, "Hydrogen Production by Catalytic Steam Reforming of Methanol. Part 2: Kinetics of Methanol Decomposition using C18HC Catalyst," Can. J. Chem. Eng. 60, 950-956 (1988).

9. T. E. Springer, H. S. Murray, and N. E. Vanderborgh, "Methanol Reformer System and Design for Electric Vehicles," Proc. of 20th Intersoc. Ener. Conv. Eng. Conf., Miami Beach, FL, August 18-23, 1985, p. 1-723.

10. N. E. Vanderborgh, B. E. Goodby, and T. E. Springer, "Oxygen Exchange Reactions During Methanol Reforming," Proc. of 32nd Inter. Power Sources Conf., Cherry Hill, NJ, June 9-12, 1986, p. 623.

11. M. Matsukata, S. Uemiya, and E. Kikuchi, "Copper-Alumina Spinel Catalysts for Steam Reforming of Methanul," Chem. Lett. 5, 761 (1988).

12. Q. D. Vu, M. Davidson, D. Durand, and P. Courty, "Process for Producing Hydrogen by Caralytic Steam Reforming of Mettannl," European Patent Application EP 272182 (June 1988).

13. Y. S. Lee, C. S. Han, M. S. Cho, and K. S. Rhee, "Decomposition of Methanol-Water on $\mathrm{Mg} / \mathrm{Ca} / \mathrm{ZnO}$ System," Taehan Hwahakhoe Chi 32 (1), 22 (1988).

14. A. Kaufman and J. Werth, "Develop and Test Fuel Cell Powered On-site Integrated Total Energy Systems," National Aeronautics and Space Adminiatration Report DOE/NASA/0241-12, NASA CR-174951 (October 1984).

15. M. Shimomura and S. Nojima, "Preparation of Monolith-type Catalyst for Methanol Steam Reforming," Japanese Kokai Tokkyo Koho, JP 62061643 (March 1987).

16. J. W. Jenkins and E. Shutt, "The Hot Spot ${ }^{\text {TM }}$ Reactor. Hydrogen Generation using - Novel Concept," Plat. Met. Rev. 33, (3), 118-127 (1989). 
17. N. Rohatgi and G. E. Voecks, "Effect of Improved Heat Transfer Catalyst Support on Steam Reforming of Methane," 1986 Fuel Cell Seminar Abstracts, Tucbon, AZ, October 26-29, 1986, pp. 292-294.

18. R. Norris Shreve and Joseph A. Brink, Jr., Chemical Process Industries, 4th Ed., McGraw-Hill Book Company, New York, pp. 98-104 (1977).

19. H. Yoshioka and M. Umemoto, "Manufacture of Hydrogen by Catalytic Reforming of Methanol," Japanese Kokaj Tokkyo Koho, JP 62246802 (October 1987).

20. A. Seya, M. Umemoto, and H. Yoshioka, "Methanol Reformer with Short Start-up Time," Japanese Kokaj Trkkyo Koho, JP 010282 2 (January 1989).

21. Y. Kubo, Y. Takatani, and S. Takao, "Reactors for Methanol Raforming," Japanese Kokai Tokkyo Koho, JP 01141802 (June 1989).

22. I. Kitamura, "Apparatus for Steam Reforning of Hydrocarbon Gases," Japanese Kokai Tokkyo Koho, JP 61256903 (November 1986).

23. S-I. Wang, "Enhanced Heat Transfer Reformer and Method," European Patent Application, EP 171786 (February 1986).

24. A. Fuderer, "Integrated Process and Apparatus for the Primary and Secondary Catalytic Steam Reforming of Hydrocarbons," U. S. Patent 4650651 (March 1987).

25. Research and Development of a Fuel Cell/Battery Powered Bus System. Phase I Final Technical Report, DOE/CH/10714-01, prepared by Energy Research Corp., Danbury, CT (December 1989).

26. Research and Development of a Fuel Cell/Battery Powered Bus System. Phase I Final Technical Report, DOE/CH/10650-01, prepared by Broz, Allen \& Hamilton, Inc., Bethesda, MD (February 1990).

27. N. E. Vanderborgh, J. Guante, R. E. Dean, Jr., and R. D. Suthon, "Methanol Fuel Processing for Low-Temperature Fuel Cells," 1988 Fuel Cell Seminar Abstracts, Long Beach, CA, October 23-26, 1988, pp. 52-55.

28. H. Stahl, J. Rostrup-Nielsen, and N. R. Udengaard, "High Efficiency Heat Exchange Reformer, ${ }^{n} 1985$ Fuel Cell Seminar Abstracis, Tucson, AZ, May 19-22, 1985, pp. 8388.

29. W. A. Summers, W. G. Parker, D. M. Rastler, N. R. Udengaard, and L. J. Christiansen, "Fuel Processing System Development and Reformer Test Results," 1986 Fuel Cell Seminar Abstracts, Tucson, AZ, October 26-29, 1986, pp. 135-139.

30. N. R. Udengaard, I. J. Christiansen, and D. M. Rastler, "Demonstration Results of a Heat Exchange Reformer for Fuel Cell Application," 1988 Fuel Cell Seminar Abstracts, Phoenix, AZ, Hovember 25-28, 1990, pp. 47-51. 
31. "Reforming of Methanol at Medium Temperature," in Solid State Material Low Temperature Fuel Cell Monitors. Special Emphasis: Proton Conductance, J. B. Goodenough, J. Jensen, and M. Kleitz, eds., Odense University Press, Odense, Denmark (1983).

32. K. Koide, "Apparatus for Hydrogen Production by Methanol Reforming," Japanese Kokai Tokkyo Koho, JP 63295403 (December 1988).

33. K. Shimada, R. Yamada, S. Nokita, and Y. Naganuma, "Apparatus for Steam Reforming of Hydrocarbon Gases," Japanese Kokai Tokkyo Koho, JP 63129002 (June 1988).

34. S. Matsumoto and A. Sasaki, "Apparatus for Steam Reforming of Methanol to Produce Hydrogen-Rich Gas," Japanese Kokai Tokkyo Koho, JP 63042733 (February 1988).

35. M. Flytzani-Stephanopoulos and G. E. Voecks, Conversion of Hydrocarbons for Fuel Cell Applications, jet Propulsion Laboratory Report 82-37, DOE/ET-113261 (October 1981).

36. T. Watanabe, M. Koga, and S. Morishima, "Plate Reformer for Molten Carbonate Fuel Cell," 1988 Fuel Cell Seminar Abstracts, Long Beach, CA, ()ctober 23-26, 1988, pp. 56-59.

37. L. J. Nutall, "Conceptual Design Study of SPE Fuel Cell Power Plant for Vehicular Applications," P. Jceedings, Renewable Fuels and Advanced Power Sources for Transportation Workshop, H. L. Chum and S. Sriaivasan, eds., National Renewable Energy Laboratory Report SERI/CP-234-1707, pp. 93-107 (1982).

38. W. J. Lywood, "Production of Hydrogen Generating Gas Streams," British UK Patent Application, GB 2231496 (August 1989).

39. W. J. Lywood, "Two-Step Steam Reforming Process," European Patent Application, EP 334540 (September 1989).

40. G. J. Sandelli and R. A. Sederquist, Demonstrate Cyclic Reforming of Logistic Fuel for Fuel Cell Power Plant, International Fuel Cells Corp. Report DAAK70-85-C-0091 (May 1986).

41. H. Matsuoka, S. Takenaka, T. Toida, and T. Koji, "Hydrogen Production by Steam Reforming of Methanol," Japanese Kokai Tokkyo Koho, JP 62007601 (January 1987).

42. Personal communication from L. Greiner, Chemical Energy Specialists, Costa Mesa, CA, to M. Krumpelt, Argonne National Laboratory, July 12, 1990.

43. J. G. Finegold, "Reformed Methanol Vehicle System Considerations," 18th Intersoc. Ener. Conv. Eng. Conf., Orlando, FL, August 21-26, 1983, Vol. 2, pp. 557-563. 
Distribution for ANL-92/31

Internal:
S. Ahmed
J. E. Harmon
P. A. Nelson
J. G. Asbury
M. Krumpelt
M. J. Steindler
I. D. Bloom
TG. H. Kucera
C. C. Christianson
R. Kumar (20)
D. W. Dees
J. F. Miller
H. Drucker
K. M. Myles
ANL Patent Dept.
ANL Contract File
TIS Files (3)

\section{External:}

DOE-OSTI, for distribution per UC-333 (187)

ANL Library

Manager, Chicago Operations Office, DOE

Chemical Technology Division Review Committee Members:

S. Baron, Brookhaven National Laboratory, Upton, NY

D. L. Douglas, Consultant, Bloomington, MN

N. Jarrett, Noel Jarrett Associates, Lower Burrell, PA

J. G. Kay, Drexel University, Philadelphia, PA

J. Stringer, Electric Power Research Institute, Palo Alto, CA

J. B. Wagner, Arizona State University, Tempe, AZ

R. G. Wymer, Oak Ridge National Laboratory, Oak Ridge, TN

S. G. Abens, Energy Research Corp., Danbury, CT

J. Allsup, USDOE, Office of Alternative Fuels, Washington, DC

A. J. Appleby, Texas A\&M University, College Station, TX

K. F. Barber, USDOE, Office of Transportation Technologies, Washington, DC

B. Bates, Ford Motor Co., Dearborn, MI

T. F. Bechtel, USDOE, Morgantown Energy Technology Center, Morgantown, WV

J. Bentley, Arthur D. Little, Inc., Cambridge, MA

J. J. Brogan, USDOE, Div, of Energy Utilization Research, Washington, DC

P. J. Brown, USDOE, Division of Electric and Hybrid Propulsion, Washington, DC

A. F. Burke, EG\&G Idaho/INEL, Idaho Falls, ID

E. J. Cairns, Lawrence Berkeley Laboratory, Berkeley, CA

H. Creueling, Allison Gas Turbine Division, General Motors Corp., Indianapolis, IN

W. J. Dollard, Westinghouse Electric Corp., Pittsburgh, PA

M. Ewan, Energy Partners, West Palm Beach, FL

E. Gillis, Electric Power Research Institute, Palo Alto, CA

R. Goldstein, Electric Power Research Institute, Palo Alto, CA

P. G. Grimes, Exxon, Annandale, NJ

J. A. Gunsher, Dow Chemical USA, Midland, MI

G. L. Hagey, EA Mueller, Baltimore, MD 
D. Hooie, USDOE, Morgantown Energy Technology Center, Morgantown, WV

G. Hossepian, Allied-Signal Aerospace Co., Torrance, CA

J. R. Huff, Los Alamos National Laboratory, Los Alamos, NM

A. Kaufman, H-Power Corp., Belleville, NJ

L. Keck, Johnson Matthey, West Deptford, NJ

J. J. Kelly, Electrodex Laboratories, Inc., Willingboro, NJ

R. J. Kevala, H-Power Corp., Rockville, MD

K. Kinoshita, Lawrence Berkeley Laboratory, Berkeley, CA

K. W. Klein, USDOE, Office of Energy Storage and Distribution, Washington, DC

R. A. Kost, USDOE, Office of Conservation \& Renewable Energy, Washington, DC

A. R. Landgrebe, USDOE, Office of Transportation Technologies, Washington, DC

R. A. Lemons, Los Alamos National Laboratory, Los Alamos, NM

J. Leonard, South Coast Air Quality Management District, El Monte, CA

Technical Library, Electrochimica Corp., Mountain View, CA

A. C. Lloyd, South Coast Air Quality Management District, El Monte, CA

W. J. Lueckel, International Fuel Cells, South Windsor, CT

M. J. Mayfield, USDOE, Morgantown Energy Technology Center, Morgantown, WV

F. R. McLarnon, Lawrence Berkeley Laboratory, Berkeley, CA

D. Mikoryak, Engineering Transportation Manufacturing Corp., Roswell, NM

P. G. Patil, USDOE, Div. of Electric and Hybrid Propulsion, Washington, DC

C. E. Pax, USDOE, Office of Fossil Energy, Germantown, MD

P. Prokopius, NASA Lewis Research Center, Cleveland, $\mathrm{OH}$

V. P. Roan, University of Florida, Gainesville, FL

S. Romano, Georgetown University, Washington, DC

R. L. San Martin, USDOE, Office of Renewable Energy, Washington, DC

R. L. Scheffler, Southern California Edison, Rosemead, CA

J. S. Siegel, USDOE, Office of Fossil Energy, Germantown, MD

W. A. Siegel, USDOE, Office of Transportation Technologies, Washington, DC

G. D. Skellenger, General Motors Research Labs, Warren, MI

D. Squire, Defense Advanced Research Projects Agency, Arlington, VA

R. D. Sutton, Allison Gas Turbine Division, General Motors Corp., Indianapolis, IN

R. Swaroop, Electric Power Research Institute, Palo Alto, CA

S. Swathirajan, General Motors Research Laboratories, Warren, MI

P. Teagan, Arthur D. Little, Inc., Cambridge, MA

K. Trimble, Gas Research Institute, Chicago, IL

N. R. Udengaand, Haldor Topsoe, Inc., Houston, TX

N. Vanderborgh, Los Alamos National Laboratory, Los Alamos, NM

J. Voecks, Jet Propulsion Laboratory, California Institute of Technology, Pasadena, CA 

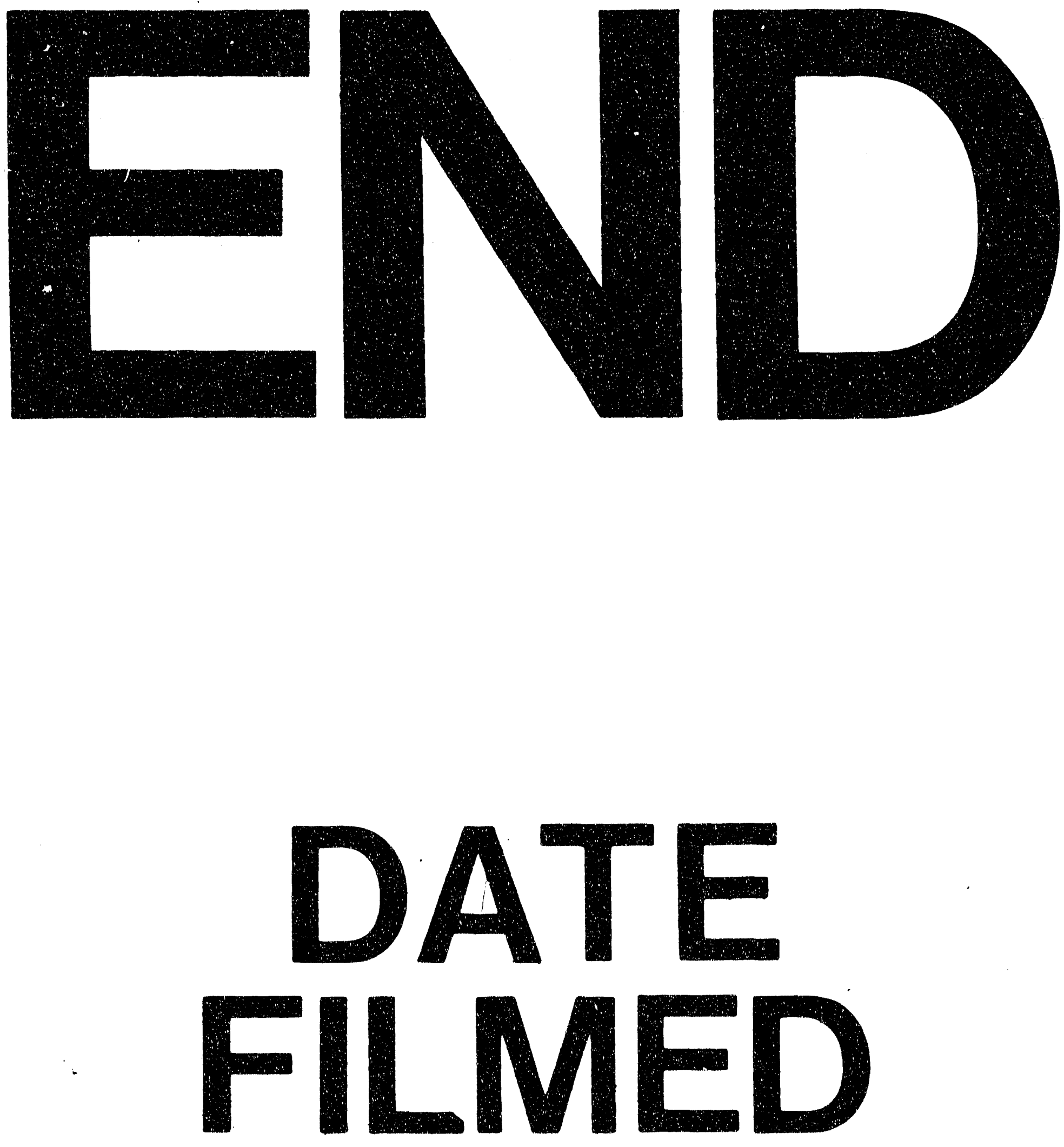

$\bar{z}$
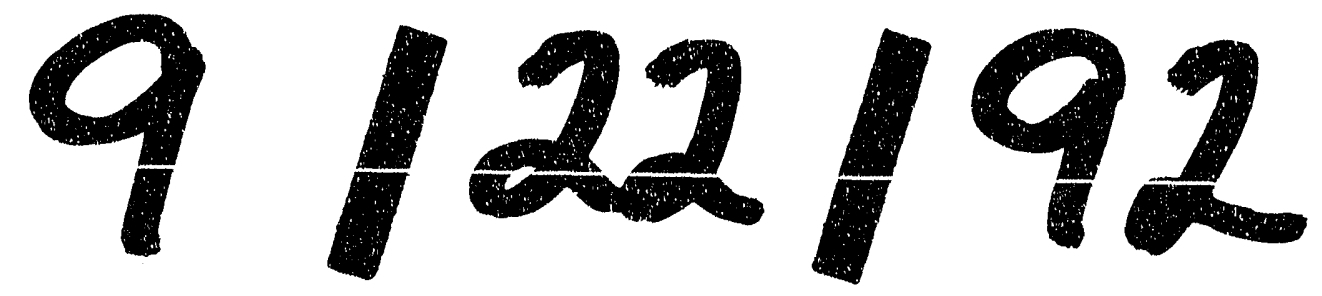
